\title{
Surgical site infection at chest tube drainage site following pulmonary resection for malignant lesions
}

\author{
Takashi Akiyama, Motoki Yano, Hiroki Numanami, Masayuki Yamaji, Rumiko Taguchi, Chihiro Furuta, \\ Yuka Kitagawa, Rintaro Imazu, Masayuki Haniuda \\ Division of Chest Surgery, Department of Surgery, Aichi Medical University, Nagakute, Japan \\ Contributions: (I) Conception and design: M Yano; (II) Administrative support: M Haniuda; (III) Provision of study materials or patients: T Akiyama, \\ M Yamaji, R Taguchi; (IV) Collection and assembly of data: C Furuta, H Numanami, Y Kitagawa; (V) Data analysis and interpretation: C Furuta, H \\ Numanami, R Imazu; (VI) Manuscript writing: All authors; (VII) Final approval of manuscript: All authors. \\ Correspondence to: Motoki Yano, 1-1 Yazakokarimata, Nagakute 480-1195, Japan. Email: yano.motoki.369@aichi-med-u.ac.jp.
}

\begin{abstract}
Background: We sometimes experience postoperative surgical site infection (SSI) at the chest tube drainage site (CDS) after thoracotomy. The incidence of and risk factors for SSI at the CDS have remained unclear.

Methods: We conducted a prospective study to determine the incidence and risk factors for SSI at the CDS. We analyzed 99 patients who underwent lobectomy or segmentectomy for pulmonary malignant lesions.

Results: There were 56 males and 43 females with an average age of 71 years. The postoperative drainage period was 2-15 days. Bacterial species were detected in secretions in 18 of 99 cases (18.2\%). Older age was a risk factor for the detection of bacteria at the timing of chest tube removal. Eighteen cases (18.2\%) were diagnosed with presence of SSI at the CDS at the timing of staple or suture removal. A pathological diagnosis of squamous cell carcinoma was regarded as a candidate risk factor for SSI. Eleven of 18 SSI patients showed delayed wound healing. A higher level of HbAlc was found in patients with delayed wound healing. Enterococcus faecalis infection may influence the development of complex SSI.

Conclusions: We identified the bacterial profiles, incidence of and risk factors for SSI at the CDS. More intense preoperative glycemic control and an understanding of the bacterial profile and may be useful for reducing the incidence of SSI chest tube drainage sites (CDS).
\end{abstract}

Keywords: Surgical site infection (SSI); chest tube drainage site (CDS)

Submitted Aug 11, 2020. Accepted for publication Jan 08, 2021.

doi: $10.21037 /$ jtd-20-2647

View this article at: http://dx.doi.org/10.21037/jtd-20-2647

\section{Introduction}

The results of surgical treatment have been improved by advances in aseptic approaches and antibiotic prophylaxis in surgical interventions (1-4). However, even though the incidence of surgical site infection (SSI) has been decreasing, SSI sometimes becomes problematic. SSI affects the skin, subcutaneous tissue, muscles, and thoracic cavity in thoracic surgery. SSI is characterized by clinical evidence of infection, purulent discharge, bacterial growth in a wound culture, or the presence of inflammatory findings in the 30 days following surgery $(5,6)$. The risk factors for SSI have been reported to include age, immune status, history of malignancy, systemic infection, long hospitalization, and other variables. Recently, the use of sterile wound drapes has been recommended to decrease SSI (7-9). However, the chest tube drainage site (CDS) often shows inflammation or delayed wound healing, even with the use of sterile wound drapes and antibiotic prophylaxis. The aim of this study is to determine the bacterial profile, incidence of and risk factors for SSI at the CDS following thoracic surgery. We present 
the following article in accordance with the STROBE reporting checklist (available at http://dx.doi.org/10.21037/ jtd-20-2647).

\section{Methods}

We conducted a prospective cohort study to determine the incidence of and risk factors for SSI at the CDS following thoracic surgery. This study was conducted in accordance with the Declaration of Helsinki (as revised in 2013). The ethics committee of Aichi Medical University approved the present clinical study (2018-H288). Written informed consent was obtained from all patients who participated in this study. A schematic representation of the study design is shown in Figure 1. At the timing of chest tube drain removal, the CDS shows inflammatory findings or pains in the most cases with varying degrees. Then, we evaluated SSI at the timing of the removal of all sutures and staples and afterwards. The presence of inflammatory findings and delayed wound healing at the CDS were suggested to be determinants of SSI. The primary endpoint of this study was to determine the incidence of SSI at the timing of the removal of all sutures and staples at the CDS. The secondary endpoints were to determine the risk factors for SSI at the CDS. Thus, patient demographics and factors related to wound healing, including comorbidities (diabetes mellitus, hypertension, cardiac disease, history of other malignancy, etc.) were analyzed. Preoperative glycemic control was performed for all patients with diabetes. We basically followed the guideline for the prevention of SSI of The Centers for Disease Control and Prevention (CDC) to reduce the risk of postoperative SSI $(5,6)$. Immediately before the operation, $1 \mathrm{~g}$ of cefazolin sodium was administered intravenously; this was repeated if the operation was prolonged, according to the instructions of the guideline. In addition, all patients were prescribed cefditoren pivoxil for 5 days for the purpose of preventing SSI, because a chest tube drain is usually inserted for 3-4 days after surgery.

This study started in January 2019. Patients who underwent lobectomy or segmentectomy to treat malignant pulmonary lesions at our institution were eligible for inclusion in the present study. Patients who underwent wedge resection for an intraoperative pathological diagnosis prior to lobectomy or segmentectomy were included in this study. Patients who had been diagnosed with benign lesions and undergone wedge resection were excluded. The chest drain tube was removed promptly after the doctors' decision. At removal, the secretion was subjected to a bacterial examination. The CDS was covered by the hydrocolloid dressing of Karayahesive ${ }^{\circledR}$ (Alcare, Tokyo, Japan) and transparent waterproof sealant. The dressings were not exchanged in principle unless they were peeled off. The staples or sutures of the CDS were removed one to two weeks after tube removal (10). At the timing of staple/suture removal, the wound was observed to detect signs of infection: redness, swelling, pus discharge, and wound dehiscence. If such infectious signs were noted, we considered it to be indicative of an SSI of the CDS, and a second bacterial examination of the secretion was performed. If necessary, the wound was treated using oral antibiotics or ointment. After staple/suture removal, we asked the patients and/or their family to observe the CDS and record the condition regardless of the presence of an SSI until CDS wound healing. In patients with an SSI, one week after the staple/suture removal, the next visit to the clinic was planned, and we deemed wound healing to be delayed when the CDS wound had not healed. In patients without an SSI, we collected information on the CDS wound healing at the next visit.

We set the variables to be analyzed as possible risk factors for the detection of pathogens at the CDS, SSI and delayed wound healing as the age; gender; body mass index (BMI); comorbidity; Charlson comorbidity index; smoking history; values of $\mathrm{HbA1c}$, albumin, and cholinesterase; approach of operation [thoracotomy, video-assisted thoracic surgery (VATS), or robot-assisted thoracic surgery (RATS)]; operation performed (lobectomy or segmentectomy); operation time; pathological diagnosis; pathological stage; and postoperative drainage period. The values of $\mathrm{HbA1c}$, albumin, and cholinesterase were included at the recommendation of the infection control team.

\section{Statistical analyses}

The EZR software program was used to perform the statistical analyses (10). The required number of cases was ere calculated using the optimal method. The unacceptable response rate and the desirable response rate were set as 0.8 and 0.9 , respectively. The alpha and beta error rates were set as 0.05 and 0.2 , respectively. As a result, the required number of cases was determined to be 97 . We therefore set the registration number to 100 cases. The primary study endpoint was the incidence of bacterial infection and delayed wound healing of the CDS following pulmonary resection for malignant pulmonary lesions. The secondary 
clinical endpoints to determine the risk factors for SSI. Values were presented as the mean \pm standard deviation and were analyzed by the non-paired $t$-test using Fisher's method. Nonparametric values were assessed using the Mann-Whitney $U$ test. The significance of differences between categorized groups was evaluated using Pearson's $\chi^{2}$ test. $\mathrm{P}$ values of $<0.05$ were considered to indicate statistical significance. Multivariate analysis was performed using the logistic regression analysis.

\section{Results}

\section{Clinical course and outcomes (Table 1)}

Although we initially planned to enroll 100 patients in the present study, 107 were ultimately enrolled. Eight patients were excluded because of benign lesions, so 99 patients were finally analyzed (Figure 1). The clinical and pathological data of all 99 patients are listed in Table 1. There were 56 males and 43 females with a median age of 72 years (range, 42-87 years). 76 patients had comorbidities. 50 had a smoking history ( $>20$ pack-year). We preoperatively measured serum HbA1c, albumin, and cholinesterase as candidate factors related to delayed wound healing; the mean \pm SD levels were $6.0 \% \pm 0.6 \%$ (institutional normal range, 4.6-6.2\%), 4.1 $\pm 0.3 \mathrm{~g} / \mathrm{dL}(4.0-$ $5.0 \mathrm{~g} / \mathrm{dL})$, and $313 \pm 66 \mathrm{U} / \mathrm{L}(214-466 \mathrm{U} / \mathrm{L})$, respectively. The pathological diagnoses were adenocarcinoma $(n=70)$, squamous cell carcinoma $(n=20)$ and others $(n=9)$, including small cell carcinoma $(n=3)$, metastatic carcinoma $(n=3)$, adenosquamous carcinoma $(\mathrm{n}=1)$, large cell carcinoma $(\mathrm{n}=1)$, and pleomorphic carcinoma $(\mathrm{n}=1)$. The pathological stages were diagnosed as Stage $0(n=5)$, IA $(n=63)$, IB $(n=8)$, IIA $(n=2)$, IIB $(n=13)$, IIIA $(n=4)$, and IVA $(n=1)$. The operations performed were lobectomy $(\mathrm{n}=88)$ and segmentectomy $(\mathrm{n}=11)$. The approach of lobectomy or segmentectomy was used with thoracotomy $(n=13)$, VATS $(n=72)$, or RATS $(n=14)$. The mean operation time was $224 \pm 63 \mathrm{~min}$. The average postoperative drainage period was 4.8 days (range, 2-15 days). The staples or sutures were removed one to two weeks after tube removal in all cases. The presence of SSI at the CDS was diagnosed with infectious signs according to the doctor's subjective judgement at the timing of staple or suture removal in 18 patients (18.2\%). One patient required re-suturing due to wound dehiscence following staple and suture removal. Other wounds besides the CDS were also observed. No SSIs were recognized, and no re-suturing or ointment treatment was needed at the other wounds.
Eleven of the 18 patients with SSI showed delayed wound healing $(11.1 \%)$. In the 11 patients with delayed wound healing, wound healing was achieved at $29 \pm 8$ days after the operation. This was significantly longer in comparison to patients without delayed wound healing $(\mathrm{n}=88,16 \pm 5$ days, $\mathrm{P}=9.9 \mathrm{e}^{-12}$ ).

\section{The statistical analysis of the relationship between the detection of pathogens and SSI (Tables 2-4)}

Pathogens were detected from the secretion of the CDS at the timing of chest tube removal in 18 of 99 patients $(18.2 \%)$. Five of the 18 patients with the detection of pathogens at chest tube removal showed an SSI at the CDS at the timing of suture and/or staple removal. In the other 13 patients who were diagnosed with SSI of the CDS at the timing of suture and/or staple removal, pathogens were not detected from the secretions at the timing of chest tube removal. There was no relationship between the detection of pathogens at the timing of chest tube removal and following SSI of the CDS at the timing of suture and/or staple removal $(\mathrm{P}=0.309)$. Similarly, there was no relationship between the detection of pathogens at the timing of chest tube removal and subsequent delayed wound healing at the CDS $(\mathrm{P}=0.683)$. As stated above, 11 of 18 SSI patients showed delayed wound healing and delayed wound healing was closely correlated with SSI $\left(\mathrm{P}=2.5 \mathrm{e}^{-10}\right)$.

\section{Risk factors for detection of pathogens, SSI and delayed wound healing at CDS (Tables 5-7)}

The patients in whom pathogens were detected from secretions at the timing of chest tube removal were older than the patients in whom bacteria were not detected $(75$ vs. 70 years, respectively). Other factors were not related to the detection of bacteria. The pathological diagnosis of squamous cell carcinoma was a risk factor for both SSI at the CDS at the timing of suture and/or staple removal and delayed wound healing. In addition, a higher HbAlc level was a risk factor for delayed wound healing. However, neither the diagnosis of squamous cell carcinoma nor an elevated HbA1c level were significant $(\mathrm{P}=0.072$ and 0.11 , respectively) in a multivariate analysis.

\section{Bacterial profile of the CDS at the timing of tube removal and the timing of suture and/or staple removal}

The bacterial profile of the CDS at the timing of chest tube 
Table 1 Clinical and pathological factors

\begin{tabular}{|c|c|}
\hline Factors & Data \\
\hline \multicolumn{2}{|l|}{ Preoperative factors } \\
\hline Age, median and range [years] & $72[42-87]$ \\
\hline \multicolumn{2}{|l|}{ Gender } \\
\hline Men & 56 \\
\hline Women & 43 \\
\hline $\mathrm{BMI}$, mean $\pm \mathrm{SD}\left(\mathrm{kg} / \mathrm{m}^{2}\right)$ & $22.5 \pm 3.3$ \\
\hline \multicolumn{2}{|l|}{ Charlson comorbidity index } \\
\hline 0 & 44 \\
\hline $1-2$ & 41 \\
\hline $3-4$ & 12 \\
\hline 5 & 2 \\
\hline \multicolumn{2}{|l|}{ Comorbidity } \\
\hline+ & 76 \\
\hline- & 23 \\
\hline \multicolumn{2}{|l|}{ Smoking history } \\
\hline+ & 50 \\
\hline- & 49 \\
\hline $\begin{array}{l}\mathrm{HbA1c} \text {, mean } \pm \mathrm{SD}(\%) \text {, (Normal range, } \\
4.6-6.2)\end{array}$ & $6.0 \pm 0.6$ \\
\hline $\begin{array}{l}\text { Alb, mean } \pm S D(g / d L), \text { (Normal range, } \\
4.0-5.0)\end{array}$ & $4.1 \pm 0.3$ \\
\hline $\begin{array}{l}\text { Choline esterase, mean } \pm \text { SD }(\mathrm{U} / \mathrm{L}) \text {, } \\
\text { (Normal range, 214-466) }\end{array}$ & $313 \pm 66$ \\
\hline \multicolumn{2}{|l|}{ Operative and postoperative factors } \\
\hline \multicolumn{2}{|l|}{ Approaches of operation } \\
\hline Thoracotomy & 13 \\
\hline VATS & 72 \\
\hline RATS & 14 \\
\hline \multicolumn{2}{|l|}{ Performed operation } \\
\hline Lobectomy & 88 \\
\hline segmentectomy & 11 \\
\hline Operation time, mean \pm SD (minutes) & $224 \pm 63$ \\
\hline \multicolumn{2}{|l|}{ Pathological diagnoses } \\
\hline Adenocarcinoma & 70 \\
\hline Squamous cell carcinoma & 20 \\
\hline Others & 9 \\
\hline
\end{tabular}

Table 1 (continued)
Table 1 (continued)

\begin{tabular}{|c|c|}
\hline Factors & Data \\
\hline \multicolumn{2}{|l|}{ Pathological stages } \\
\hline 0 & 5 \\
\hline $\mathrm{IA}$ & 63 \\
\hline IB & 8 \\
\hline$\| A$ & 2 \\
\hline IIB & 13 \\
\hline IIIA & 4 \\
\hline IVA & 1 \\
\hline $\begin{array}{l}\text { Postoperative drainage period, median } \\
\text { and range [days] }\end{array}$ & $4[2-15]$ \\
\hline \multicolumn{2}{|l|}{$\begin{array}{l}\text { Reoperation for postoperative } \\
\text { complications }\end{array}$} \\
\hline Air leakage (>14 days) & 1 \\
\hline Bronchopleural fistula & 1 \\
\hline \multicolumn{2}{|l|}{$\begin{array}{l}\text { Detection of pathogen in secretions at } \\
\text { CDS at tube removal }\end{array}$} \\
\hline+ & 18 \\
\hline- & 81 \\
\hline \multicolumn{2}{|l|}{$\begin{array}{l}\text { SSI at the CDS at suture and/or staple } \\
\text { removal }\end{array}$} \\
\hline+ & 18 \\
\hline- & 81 \\
\hline \multicolumn{2}{|l|}{ Delayed wound healing at CDS } \\
\hline+ & 11 \\
\hline- & 88 \\
\hline
\end{tabular}

BMI, body mass index; VATS, video-assisted thoracic surgery; RATS, robot-assisted thoracic surgery; SSI, surgical site infection; CDS, chest tube drainage site.

removal and at the timing of suture and/or staple removal is shown in Table 8. At the timing of chest tube removal, a single species was detected in all 18 cases. Pathogens were detected from the secretion of the CDS in 16 of the 18 patients with SSI at the timing of removal of the sutures and/or staples. Among these 16 patients, multiple species of pathogens were recognized in 5 patients. Normal epidermal flora was frequently detected; however, Enterococcus faecalis from the intestinal flora was also detected in complex pathogens. 


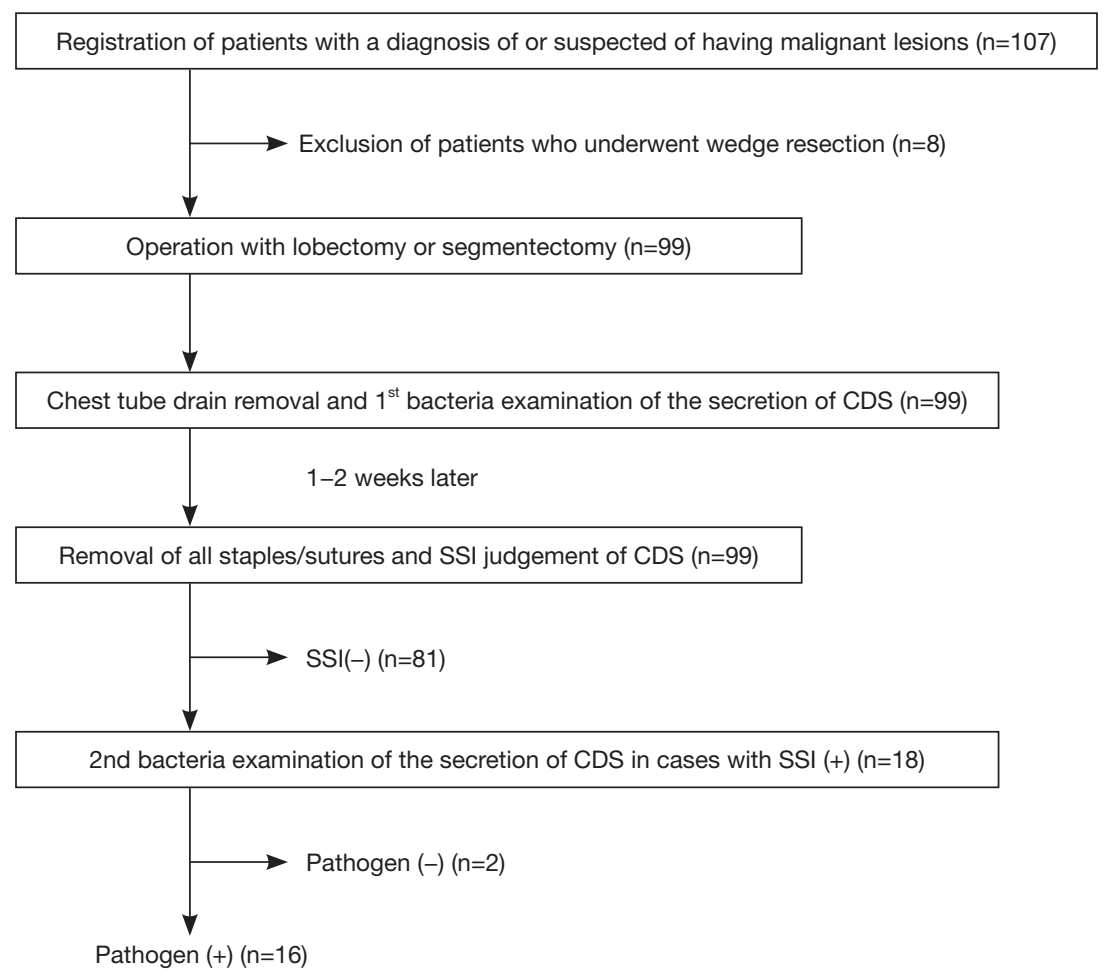

Figure 1 A schematic representation of the study design. CDS, chest tube drainage site.

Table 2 Detection of pathogen in secretions at the CDS at tube removal and at the SSI at suture and/or staple removal

\begin{tabular}{lccc}
\hline & SSI (-) & SSI (+) & P value \\
\hline Pathogen (-) & 68 & 13 & 0.309 \\
Pathogen (+) & 13 & 5 & \\
\hline
\end{tabular}

CDS, chest tube drainage site; SSI, surgical site infection

Table 3 Detection of pathogens at the CDS at tube removal and delayed wound healing

\begin{tabular}{lccc}
\hline & $\begin{array}{c}\text { Delayed wound } \\
\text { healing }(-)\end{array}$ & $\begin{array}{c}\text { Delayed wound } \\
\text { healing }(+)\end{array}$ & P value \\
\hline Pathogen $(-)$ & 71 & 10 & 0.683 \\
Pathogen $(+)$ & 17 & 1 & \\
\hline
\end{tabular}

CDS, chest tube drainage site.

\section{Discussion}

The postoperative management of chest tubes for patients undergoing lobectomy may influence the postoperative condition of the patients, length of stay in the hospital, and healthcare costs. Guidelines for the management of
Table 4 SSI at the CDS at suture/staple removal and delayed wound healing

\begin{tabular}{lccc}
\hline & SSI (-) & SSI (+) & P value \\
\hline Delayed wound healing (-) & 81 & 7 & $2.5 \mathrm{e}-10$ \\
Delayed wound healing (+) & 0 & 11 & \\
\hline SSI, surgical site infection; CDS, chest tube drainage site.
\end{tabular}

chest tube have been proposed $(11,12)$. However, SSI of the CDS after removal has not been discussed. We identified the incidence and risk factors for SSI at the CDS in the present study. We initially hypothesized that the detection of bacteria from the CDS at the timing of chest tube removal was closely related to subsequent SSI at the CDS. We planned to examine secretions at the CDS at the timing of chest tube removal. However, we recognized no relationship between the detection of bacteria at the timing of chest tube removal and subsequent SSI. The bacteria that were identified at the CDS at the timing of chest tube removal seemed to be normal epidermal flora and are often found in older patients. The patients in whom such bacteria were detected did not necessarily develop SSI. Bacteria were detected from the secretions of the CDS at the timing 
Table 5 Detection of pathogen from the secretion at tube removal

\begin{tabular}{|c|c|c|c|}
\hline Factors & $\begin{array}{l}\text { Pathogen }(+) \\
\qquad(n=18)\end{array}$ & $\begin{array}{l}\text { Pathogen }(-) \\
\quad(n=81)\end{array}$ & $P$ value \\
\hline Age, years & $75 \pm 6$ & $70 \pm 9$ & 0.024 \\
\hline Gender & & & 1.0 \\
\hline Male & 10 & 46 & \\
\hline Female & 8 & 35 & \\
\hline BMI & $22.0 \pm 2.6$ & $22.6 \pm 3.4$ & 0.46 \\
\hline \multicolumn{2}{|c|}{ Charlson comorbidity index } & & 0.17 \\
\hline 0 & 8 & 36 & \\
\hline $1-2$ & 5 & 36 & \\
\hline $3-4$ & 4 & 8 & \\
\hline 5 & 1 & 1 & \\
\hline Comorbidity & & & 0.55 \\
\hline+ & 15 & 61 & \\
\hline- & 3 & 20 & \\
\hline Smoking history & & & 1.0 \\
\hline+ & 10 & 47 & \\
\hline- & 8 & 34 & \\
\hline $\mathrm{HbA} 1 \mathrm{c}$ & $6.1 \pm 0.8$ & $6.0 \pm 0.6$ & 0.48 \\
\hline Albumin & $4.0 \pm 0.3$ & $4.1 \pm 0.6$ & 0.21 \\
\hline Choline esterase & $299 \pm 49$ & $317 \pm 69$ & 0.30 \\
\hline \multicolumn{2}{|c|}{ Approaches of operation } & & 0.27 \\
\hline Thoracotomy & 4 & 9 & \\
\hline VATS & 13 & 59 & \\
\hline RATS & 1 & 13 & \\
\hline Performed operation & & & 0.21 \\
\hline Lobectomy & 18 & 70 & \\
\hline Segmentectomy & 0 & 11 & \\
\hline Operation time, $\min$ & $213 \pm 62$ & $227 \pm 63$ & 0.41 \\
\hline Pathological diagnose & & & 0.37 \\
\hline$A D$ & 15 & 55 & \\
\hline $\mathrm{SQ}$ & 3 & 17 & \\
\hline Others & 0 & 9 & \\
\hline
\end{tabular}

Table 5 (continued)
Table 5 (continued)

\begin{tabular}{lccc}
\hline Factors & $\begin{array}{c}\text { Pathogen }(+) \\
(\mathrm{n}=18)\end{array}$ & $\begin{array}{c}\text { Pathogen }(-) \\
(\mathrm{n}=81)\end{array}$ & P value \\
\hline Pathological stages & & 55 & 1.0 \\
pStage 0-IA & 13 & 23 & \\
pStage IB-IVA & 2 & 3 & \\
Metastatic tumor & 0 & $5 \pm 2$ & 0.26 \\
$\begin{array}{l}\text { Postoperative drainage } \\
\text { period, min }\end{array}$ & $5 \pm 4$ & &
\end{tabular}

BMI, body mass index; VATS, video-assisted thoracic surgery; RATS, robot-assisted thoracic surgery; AD, adenocarcinoma; $S Q$, squamous cell carcinoma.

Table 6 SSI at removal of suture/staple at CDS

\begin{tabular}{|c|c|c|c|}
\hline Factors & $\begin{array}{l}\text { Pathogen }(+) \\
\qquad(n=18)\end{array}$ & $\begin{array}{l}\text { Pathogen }(-) \\
\qquad(\mathrm{n}=81)\end{array}$ & $P$ value \\
\hline Age, years & $72 \pm 10$ & $71 \pm 8$ & 0.43 \\
\hline Gender & & & 0.43 \\
\hline Male & 12 & 44 & \\
\hline Female & 6 & 37 & \\
\hline BMI & $22.7 \pm 3.0$ & $22.4 \pm 3.4$ & 0.75 \\
\hline \multicolumn{2}{|c|}{ Charlson comorbidity index } & & 0.42 \\
\hline 0 & 8 & 36 & \\
\hline $1-2$ & 6 & 35 & \\
\hline $3-4$ & 3 & 9 & \\
\hline 5 & 1 & 1 & \\
\hline Comorbidity & & & 0.76 \\
\hline+ & 13 & 63 & \\
\hline- & 5 & 18 & \\
\hline Smoking history & & & 0.068 \\
\hline+ & 14 & 43 & \\
\hline- & 4 & 38 & \\
\hline $\mathrm{HbA1c}$ & $6.2 \pm 0.6$ & $6.0 \pm 0.6$ & 0.14 \\
\hline Albumin & $4.1 \pm 0.3$ & $4.1 \pm 0.3$ & 0.77 \\
\hline Choline esterase & $287 \pm 51$ & $319 \pm 67$ & 0.057 \\
\hline
\end{tabular}

Table 6 (continued) 
Table 6 (continued)

\begin{tabular}{|c|c|c|c|}
\hline Factors & $\begin{array}{l}\text { Pathogen }(+) \\
\qquad(n=18)\end{array}$ & $\begin{array}{l}\text { Pathogen }(-) \\
\quad(n=81)\end{array}$ & $P$ value \\
\hline Approaches of operation & & & 0.15 \\
\hline Thoracotomy & 3 & 10 & \\
\hline VATS & 15 & 57 & \\
\hline RATS & 0 & 14 & \\
\hline Performed operation & & & 1.0 \\
\hline Lobectomy & 16 & 72 & \\
\hline Segmentectomy & 2 & 9 & \\
\hline Operation time, min & $213 \pm 57$ & $227 \pm 64$ & 0.42 \\
\hline Pathological diagnoses & & & 0.10 \\
\hline$A D$ & 10 & 60 & \\
\hline $\mathrm{SQ}$ & 7 & 13 & \\
\hline Others & 1 & 8 & \\
\hline Pathological diagnoses 2 & & & 0.048 \\
\hline SQ & 7 & 13 & \\
\hline Non-SQ & 11 & 68 & \\
\hline Pathological stages & & & 0.88 \\
\hline pStage 0-IA & 12 & 56 & \\
\hline pStage IB-IVA & 6 & 22 & \\
\hline Metastatic tumor & 0 & 3 & \\
\hline $\begin{array}{l}\text { Postoperative drainage } \\
\text { period, min }\end{array}$ & $5 \pm 2$ & $5 \pm 3$ & 0.95 \\
\hline
\end{tabular}

SSI, surgical site infection; CDS, chest tube drainage site; BMI, body mass index; VATS, video-assisted thoracic surgery; RATS, robot-assisted thoracic surgery; $A D$, adenocarcinoma; $S Q$, squamous cell carcinoma

Table 7 Delayed wound healing at the CDS

\begin{tabular}{lccc}
\hline Factors & $\begin{array}{c}\text { Delayed } \\
\text { wound healing } \\
(+)(\mathrm{n}=11)\end{array}$ & $\begin{array}{c}\text { Delayed } \\
\text { wound healing } \\
(-)(\mathrm{n}=88)\end{array}$ & P value \\
\hline Age, years & $72 \pm 10$ & $71 \pm 8$ & 0.46 \\
Gender & & & 0.34 \\
Male & 8 & 48 & \\
Female & 3 & 40 & \\
BMl & $22.8 \pm 3.4$ & $22.4 \pm 3.3$ & 0.71 \\
\hline
\end{tabular}

Table 7 (continued)
Table 7 (continued)

\begin{tabular}{|c|c|c|c|}
\hline Factors & $\begin{array}{l}\text { Delayed } \\
\text { wound healing } \\
\qquad(+)(n=11)\end{array}$ & $\begin{array}{l}\text { Delayed } \\
\text { wound healing } \\
(-)(n=88)\end{array}$ & $P$ value \\
\hline \multicolumn{3}{|c|}{ Charlson comorbidity index } & 0.28 \\
\hline 0 & 4 & 40 & \\
\hline $1-2$ & 4 & 37 & \\
\hline $3-4$ & 2 & 10 & \\
\hline 5 & 1 & 1 & \\
\hline \multicolumn{3}{|l|}{ Comorbidity } & 0.71 \\
\hline+ & 8 & 68 & \\
\hline- & 3 & 20 & \\
\hline \multicolumn{3}{|l|}{ Smoking history } & 0.35 \\
\hline+ & 8 & 49 & \\
\hline- & 3 & 39 & \\
\hline $\mathrm{HbA1c}$ & $6.4 \pm 0.6$ & $6.0 \pm 0.6$ & 0.037 \\
\hline Albumin & $4.1 \pm 0.3$ & $4.1 \pm 0.3$ & 0.93 \\
\hline Choline esterase & $283 \pm 61$ & $317 \pm 66$ & 0.10 \\
\hline \multicolumn{3}{|c|}{ Approaches of operation } & 0.15 \\
\hline Thoracotomy & 3 & 10 & \\
\hline VATS & 8 & 64 & \\
\hline RATS & 0 & 14 & \\
\hline \multicolumn{3}{|l|}{ Performed operation } & 1.0 \\
\hline Lobectomy & 10 & 78 & \\
\hline Segmentectomy & 1 & 10 & \\
\hline Operation time, min & $220 \pm 67$ & $225 \pm 62$ & 0.80 \\
\hline \multicolumn{3}{|l|}{ Pathological diagnoses } & 0.053 \\
\hline$A D$ & 5 & 65 & \\
\hline SQ & 5 & 15 & \\
\hline Others & 1 & 8 & \\
\hline \multicolumn{3}{|c|}{ Pathological diagnoses 2} & 0.042 \\
\hline SQ & 5 & 15 & \\
\hline Non-SQ & 6 & 73 & \\
\hline \multicolumn{3}{|l|}{ Pathological stages } & 1.0 \\
\hline pStage 0-IA & 8 & 60 & \\
\hline pStage IB-IVA & 3 & 25 & \\
\hline Metastatic tumor & 0 & 3 & \\
\hline $\begin{array}{l}\text { Postoperative } \\
\text { drainage period, min }\end{array}$ & $5 \pm 2$ & $5 \pm 2$ & 0.91 \\
\hline
\end{tabular}

CDS, chest tube drainage site; BMI, body mass index; VATS, video-assisted thoracic surgery; RATS, robot-assisted thoracic surgery; $A D$, adenocarcinoma; $S Q$, squamous cell carcinoma. 
Table 8 Bacterial profile isolated from secretions at the chest tube drainage site (CDS)

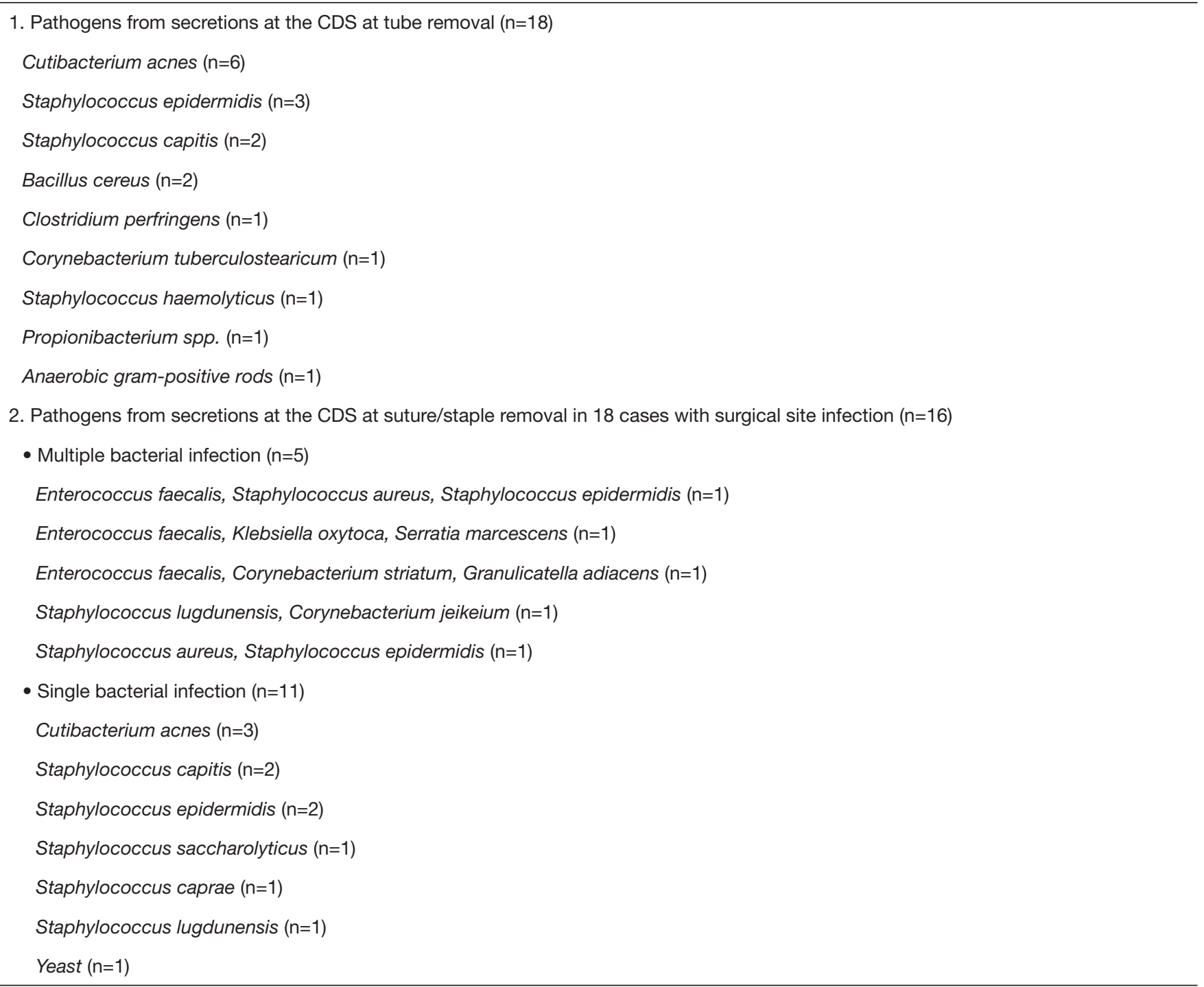

of chest tube removal in 18 of 99 patients. In all 18 cases, the detected bacterium was a single pathogen. However, the bacterial pathogens from SSI were more complex. Multiple bacterial species were detected in 5 of 16 patients (31\%).

In complex pathogens, Enterococcus faecalis was noticeable. Enterococcus faecalis is a Gram-positive coccus that is commonly detected in nosocomial infections of burn and surgical wounds as well as in the urinary tract, abdomen, pelvis and gut $(13,14)$. It is one of the most frequently detected bacteria in chronic wounds (15). Recently enterococcus faecalis has been recognized to modulate immune activation and slow healing during wound infection. It has been demonstrated that the commensal bacterium
Enterococcus faecalis contributes to the pathogenesis of anastomotic leakage through its capacity to degrade collagen and activate tissue matrix metalloprotease-9 (MMP9) in host intestinal tissues (16). Delayed wound healing of the CDS might be induced by similar mechanisms. The control of Enterococcus faecalis infection may become a key to preventing SSI and delayed wound healing. In the present study, we routinely administered $1 \mathrm{~g}$ of cefazolin sodium intravenously and prescribed cefditoren pivoxil for 5 days as antibiotic prophylaxis. This was based on assumed chest tube drainage period. As the median postoperative chest tube drainage period was 4 days, we considered that it was reasonable to administer these drugs for 5 days. In 5 of 
18 cases with pathogens at tube removal were detected with SSI and pathogens at suture/staple removal. The pathogens were same in 2 patients and in 3 patients the pathogens were different at both timings of tube removal and suture/ staple removal. In 13 patients with SSI pathogens were not detected at tube removal and in 11 of 13 patients, pathogens were newly detected at the timing of suture/staple removal. It is difficult to explain the alteration of pathogens in the 3 patients but pathogens were newly detected in the most patients (13/18). We speculated that pathogens of SSI appeared between tube removal and suture/staple removal in the most cases. If so, the timing of administration of antibiotics may be set after the chest tube has been removed.

We have newly suggested that a pathological diagnosis of squamous cell carcinoma and a high level of HbAlc are risk factors for SSI and delayed wound healing, although we performed preoperative glycemic control according to the instructions of the CDC. As the comorbidity of diabetes has been widely regarded as a risk factor for delayed wound healing $(17,18)$, it is not easy to prevent SSI in patients with diabetes, even with preoperative glycemic control. We reaffirmed the importance of glycemic profile optimization.

Of note, the pathological diagnosis of squamous cell carcinoma was suggested to be a risk factor for SSI and delayed wound healing. As a smoking history alone was not found to be a significant risk factor, the nutrition condition, drinking habit and other factors might combine to induce SSI and delayed wound healing. To reduce the incidence of SSI of the CDS, extension of the prescription period or resuming administration after drain tube removal may be useful for patients diagnosed with squamous cell carcinoma and those with comorbid diabetes. It may also be effective to change to antibiotics that can provide broad coverage, even for Enterococcus faecalis.

Recently it has been reported that there was a relationship between normal lung microbiota and the prognosis of lung cancer (19). In the case of lung cancer patients, a bacterial analysis of the normal lung tissue, and not just the CDS, would improve the understanding of the microbiome of the lung in cancer patients may lead to improved survival in lung cancer patients.

While the results of this study are encouraging, any conclusions should be tempered by the limitations of a single institution and small number of cases. While the number of patients needed to analyze the incidence of SSI was calculated, we need more cases in order to establish the bacterial profile of SSI at the CDS. We are planning our next study to involve multiple institutions with a large number of patients. In addition, we planned the postoperative administration of oral antimicrobial agent to last for five days, even though this was not recommended in the guidelines. This decision may have influenced the relatively high incidence of SSI or delayed wound healing.

\section{Conclusions}

We identified the bacterial profile, incidence and risk factors for SSI at the CDS. More intense preoperative glycemic control and an understanding of the bacterial profile and may be useful for reducing the incidence of SSI CDS.

\section{Acknowledgments}

Funding: None.

\section{Footnote}

Reporting Checklist: The authors have completed the STROBE reporting checklist. Available at http://dx.doi. org/10.21037/jtd-20-2647

Data Sharing Statement: Available at http://dx.doi. org/10.21037/jtd-20-2647

Peer Review File: Available at http://dx.doi.org/10.21037/jtd20-2647

Conflicts of Interest: All authors have completed the ICMJE uniform disclosure form (available at http://dx.doi. org/10.21037/jtd-20-2647). The authors have no conflicts of interest to declare.

Ethical Statement: The authors are accountable for all aspects of the work in ensuring that questions related to the accuracy or integrity of any part of the work are appropriately investigated and resolved. This study was conducted in accordance with the Declaration of Helsinki (as revised in 2013). The ethics committee of Aichi Medical University approved the present clinical study (2018-H288). Written informed consent was obtained from all patients who participated in this study.

Open Access Statement: This is an Open Access article distributed in accordance with the Creative Commons Attribution-NonCommercial-NoDerivs 4.0 International 
License (CC BY-NC-ND 4.0), which permits the noncommercial replication and distribution of the article with the strict proviso that no changes or edits are made and the original work is properly cited (including links to both the formal publication through the relevant DOI and the license). See: https://creativecommons.org/licenses/by-nc-nd/4.0/.

\section{References}

1. Newsom SW. Pioneers in infection control-Joseph Lister. J Hosp Infect 2003;55:246-53.

2. Bejko J, Tarzia V, Carrozzini M, et al. Comparison of Efficacy and Cost of Iodine Impregnated Drape vs. Standard Drape in Cardiac Surgery: Study in 5100 Patients. J Cardiovasc Transl Res 2015;8:431-7.

3. Ilves R, Cooper JD, Todd TR, et al. Prospective, randomized, double-blind study using prophylactic cephalothin for major, elective, general thoracic operations. J Thorac Cardiovasc Surg 1981;81:813-7.

4. Chang SH, Krupnick AS. Perioperative antibiotics in thoracic surgery. Thorac Surg Clin 2012;22:35-45.

5. Todd B. New CDC Guideline for the Prevention of Surgical Site Infection. Am J Nurs 2017;117:17.

6. Borchardt RA, Tzizik D. Update on surgical site infections: The new CDC guidelines. JAAPA 2018;31:52-4.

7. Felbaum D, Syed HR, Snyder R, et al. Surgical adhesive drape (IO-ban) as postoperative surgical site dressing. Cureus 2015;7:e394.

8. Karapınar K, Kocatürk Cİ. The effectiveness of sterile wound drapes in the prevention of surgical site infection in thoracic surgery. Biomed Res Int 2019;2019:1438793.

9. Teshima H, Kawano H, Kashikie H, et al. A new hydrocolloid dressing prevents surgical site infection of median sternotomy wounds. Surg Today 2009;39:848-54.
10. Kanda Y. Investigation of the freely available easy-touse software 'EZR' for medical statistics. Bone Marrow Transplant 2013;48:452-8.

11. Gao S, Zhang Z, Aragón J, et al. The Society for Translational Medicine: clinical practice guidelines for the postoperative management of chest tube for patients undergoing lobectomy. J Thorac Dis 2017;9:3255-64.

12. Brunelli A, Beretta E, Cassivi SD, et al. Consensus definitions to promote an evidence-based approach to management of the pleural space. A collaborative proposal by ESTS, AATS, STS, and GTSC. Eur J Cardiothorac Surg 2011;40:291-7.

13. Mohamed JA, Huang DB. Biofilm formation by enterococci. J Med Microbiol 2007;56:1581-8.

14. Baldassarri L, Creti R, Montanaro L, et al. Pathogenesis of implant infections by enterococci. Int $\mathrm{J}$ Artif Organs 2005;28:1101-9.

15. Gjødsbøl K, Christensen JJ, Karlsmark T, et al. Multiple bacterial species reside in chronic wounds: a longitudinal study. Int Wound J 2006;3:225-31.

16. Shogan BD, Belogortseva N, Luong PM, et al. Collagen degradation and MMP9 activation by Enterococcus faecalis contribute to intestinal anastomotic leak. Sci Transl Med 2015;7:286ra68.

17. Golden SH, Peart-Vigilance C, Kao WH, et al. Perioperative glycemic control and the risk of infectious complications in a cohort of adults with diabetes. Diabetes Care 1999;22:1408-14.

18. Dronge AS, Perkal MF, Kancir S, et al. Longterm glycemic control and postoperative infectious complications. Arch Surg 2006;141:375-80.

19. Peters BA, Hayes RB, Goparaju C, et al. The Microbiome in Lung Cancer Tissue and Recurrence-Free Survival. Cancer Epidemiol Biomarkers Prev 2019;28:731-40.
Cite this article as: Akiyama T, Yano M, Numanami H, Yamaji M, Taguchi R, Furuta C, Kitagawa Y, Imazu R, Haniuda M. Surgical site infection at chest tube drainage site following pulmonary resection for malignant lesions. J Thorac Dis 2021;13(3):1445-1454. doi: 10.21037/jtd-20-2647 